\title{
Lower daily carbohydrate consumption than recommended by the Institute of Medicine is common among women with type 2 diabetes in early pregnancy in Denmark
}

Ásbjörnsdóttir, Björg; Ronneby, Helle; Vestgaard, Marianne; Ringholm, Lene; Nichum, Vibeke Ladefoged; Jensen, Dorte M; Raben, Anne; Damm, Peter; Mathiesen, Elisabeth R

Published in:

Diabetes Research and Clinical Practice

DOI:

10.1016/j.diabres.2019.05.012

Publication date:

2019

Document version

Peer reviewed version

Document license:

CC BY-NC-ND

Citation for published version (APA):

Ásbjörnsdóttir, B., Ronneby, H., Vestgaard, M., Ringholm, L., Nichum, V. L., Jensen, D. M., Raben, A., Damm, P., \& Mathiesen, E. R. (2019). Lower daily carbohydrate consumption than recommended by the Institute of Medicine is common among women with type 2 diabetes in early pregnancy in Denmark. Diabetes Research and Clinical Practice, 152, 88-95. https://doi.org/10.1016/j.diabres.2019.05.012 


\section{Accepted Manuscript}

Lower daily carbohydrate consumption than recommended by the Institute of Medicine is common among women with type 2 diabetes in early pregnancy in

Denmark

Björg Ásbjörnsdóttir, Helle Ronneby, Marianne Vestgaard, Lene Ringholm, Vibeke L. Nichum, Dorte M. Jensen, Anne Raben, Peter Damm, Elisabeth R. Mathiesen

PII: S0168-8227(18)31890-4

DOI: https://doi.org/10.1016/j.diabres.2019.05.012

Reference: DIAB 7733

To appear in: Diabetes Research and Clinical Practice

Received Date: $\quad 20$ December 2018

Revised Date: $\quad 9$ May 2019

Accepted Date: 13 May 2019

Please cite this article as: B. Ásbjörnsdóttir, H. Ronneby, M. Vestgaard, L. Ringholm, V.L. Nichum, D.M. Jensen, A. Raben, P. Damm, E.R. Mathiesen, Lower daily carbohydrate consumption than recommended by the Institute of Medicine is common among women with type 2 diabetes in early pregnancy in Denmark, Diabetes Research and Clinical Practice (2019), doi: https://doi.org/10.1016/j.diabres.2019.05.012

This is a PDF file of an unedited manuscript that has been accepted for publication. As a service to our customers we are providing this early version of the manuscript. The manuscript will undergo copyediting, typesetting, and review of the resulting proof before it is published in its final form. Please note that during the production process errors may be discovered which could affect the content, and all legal disclaimers that apply to the journal pertain. 


\section{Lower daily carbohydrate consumption than recommended by the Institute of Medicine is} common among women with type 2 diabetes in early pregnancy in Denmark

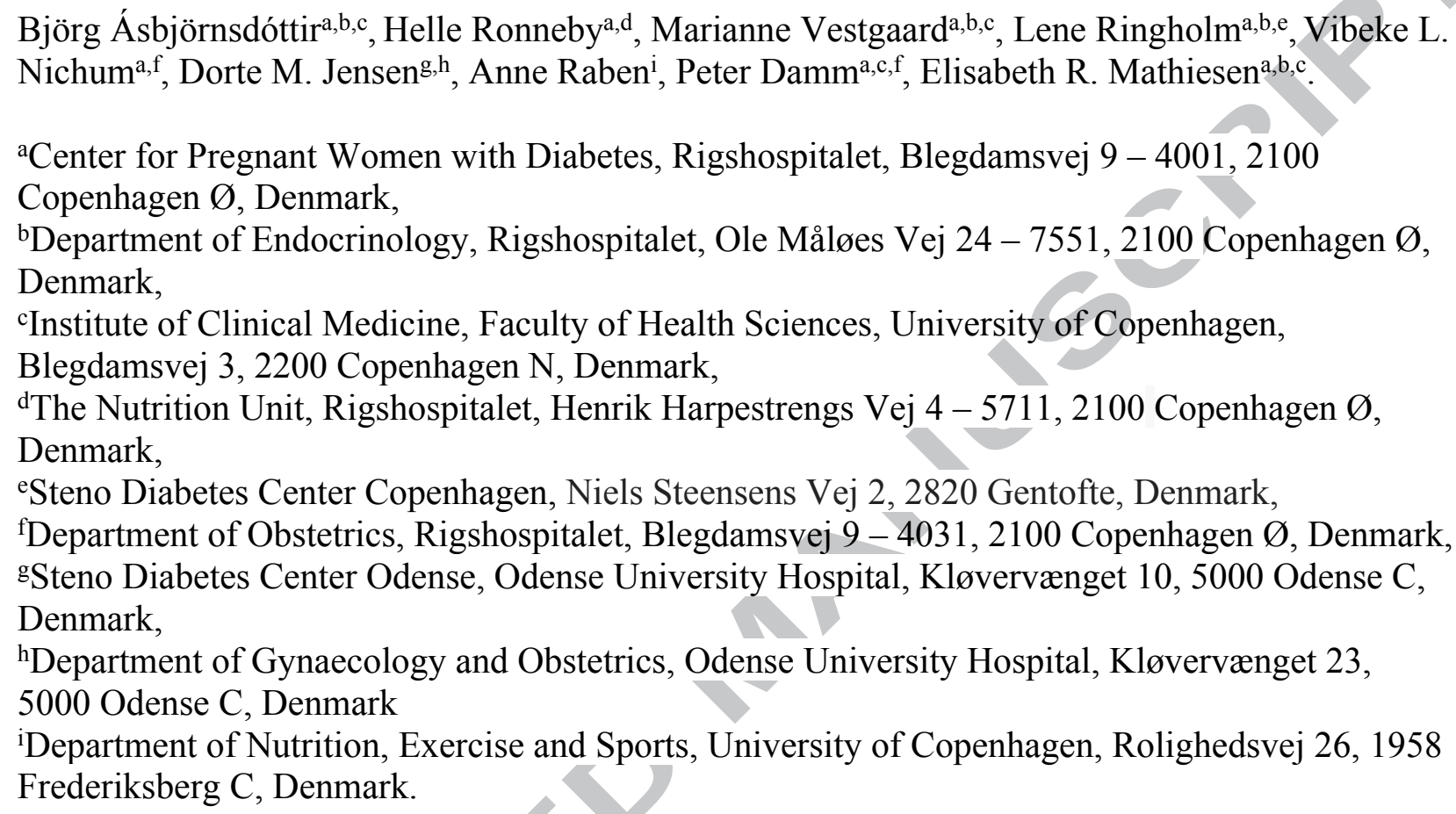

\section{E-mail addresses of the authors:}

Helle Ronneby: Helle.Ronneby@regionh.dk

Marianne Vestgaard: marianne.jenlev.vestgaard@,regionh.dk 
43 Lene Ringholm: enel@dadlnet.dk

44 Vibeke L. Nichum: vibeke.ladefoged.nichum@regionh.dk

45 Dorte M. Jensen: Dorte.Moeller.Jensen@rsyd.dk

46 Anne Raben: ara@nexs.ku.dk

47 Peter Damm: pdamm@dadlnet.dk

48 Elisabeth R. Mathiesen: elisabeth.reinhardt.mathiesen@,regionh.dk

49

50

51 
53

54

55

56

57

58

59

60

61

62

63

64

65

66

67

68

69

70

71

72

73

74

75

76

77

78

79

80

Aims:

To secure adequate carbohydrate supply in pregnancy, the Institute of Medicine (IOM) recommends a minimum amount of carbohydrates of $175 \mathrm{~g}$ daily. Currently a low carbohydrate diet is a popular health trend in the general population and this might also be common among overweight and obese pregnant women with type 2 diabetes (T2D). Thus, we explored carbohydrate consumption among pregnant women with T2D including women with type 1 diabetes (T1D) for comparison.

Methods:

A retrospective cohort study of consecutive women with T2D $(\mathrm{N}=96)$ and T1D $(\mathrm{N}=108)$, where dietary records were collected at the first antenatal visit.

Results:

Among women with T2D and T1D, bodyweight at the first visit was $90.8 \pm 22(\mathrm{mean} \pm \mathrm{SD})$ and $75.5 \pm 15 \mathrm{~kg}(\mathrm{P}<0.001)$ while $\mathrm{HbAlc}$ was $6.6 \pm 1.2 \%(49 \pm 13 \mathrm{mmol} / \mathrm{mol})$ and $6.6 \pm 0.8 \%(48 \pm 8$ $\mathrm{mmol} / \mathrm{mol}$ ), $\mathrm{P}=0.8$, respectively. The average daily carbohydrate consumption from the major carbohydrate sources was similar in the two groups ( $159 \pm 56$ and $167 \pm 48 \mathrm{~g}, \mathrm{P}=0.3$ ), as was the level of total daily physical activity (median (interquartile range)): 215 (174-289) and 210 (178-267) metabolic equivalent of task-hour/week $(\mathrm{P}=0.9)$. A high proportion of women with T2D and T1D ( $52 \%$ and $40 \%, \mathrm{P}=0.08)$ consumed fewer carbohydrates than recommended by the IOM. The prevalence of ketonuria ( $\geq 4 \mathrm{mmol} / \mathrm{L}$ ) was $1 \%$ in both groups.

\section{Conclusions:}

In early pregnancy, a lower daily carbohydrate consumption than recommended by the IOM was common among women with T2D. The results were quite similar to women with T1D, despite a markedly higher bodyweight in women with T2D. Reassuringly, ketonuria was rare in both groups.

Keywords: Carbohydrate, pregnancy, type 2 diabetes, type 1 diabetes. 
1. Introduction

Pregnancies complicated by diabetes are associated with increased risk of adverse perinatal outcomes including infants born large for gestational age $(1,2)$. This is mostly attributed to the maternal transfer of excessive glucose across the placenta leading to accelerated fetal growth (3). The total amount of carbohydrates is the main dietary factor affecting postprandial blood glucose (4). Therefore a restricted carbohydrate consumption in pregnant women with diabetes could be sensible but as both the maternal and the fetal brain mainly use glucose as an energy source, the Institute of Medicine (IOM) and the American Diabetes Association (ADA) recommend a minimum of $175 \mathrm{~g}$ of carbohydrates daily for pregnant women $(5,6)$. The average daily carbohydrate consumption in early pregnancy in healthy women is in general reported to be well above the minimum amount recommended by the $\operatorname{IOM}(7,8)$ and excessive gestational weight gain is common (9).

A low carbohydrate diet aiming at reducing plasma glucose levels and obtaining weight loss is a popular health trend in the general population (10) and in patients with type 2 diabetes (T2D) (11) but may be harmful during pregnancy. Insufficient carbohydrate consumption can lead to increased lipolysis and ketone body production and pregnant women are in general more prone to ketosis than non-pregnant women (12-14). Previous observational studies in offspring of women with diabetes suggests that elevated maternal ketone bodies may have a negative effect on the developing fetal central nervous system $(15,16)$. Thus, we speculate that, in pregnant women with diabetes, sufficient daily carbohydrate consumption and avoidance of ketonemia are probably important for normal fetal brain development.

The total amount of macronutrients required to maintain body weight is dependent on the body composition and the level of physical activity. Therefore, the recommendations on carbohydrate consumption are often given per kilo bodyweight which probably can lead to inappropriately high 
carbohydrate consumption in obese women where the recommended gestational weight gain is smaller than in normal weight women (14). High prevalence of excessive gestational weight gain has been reported among pregnant women with diabetes (17-19). Recommendations on lower energy percent $(\mathrm{E} \%)$ of carbohydrates in obese pregnant women with diabetes has been suggested $(20)$.

Modern diabetes treatment respects a flexible lifestyle (21) and the daily amount of carbohydrates varies considerably from day to day in pregnant women with type 1 diabetes (T1D) (22). In a real world, daily dietary intake may therefore vary considerably from the dietary advises given. One small study including 19 women with T2D at 22 gestational weeks found an average carbohydrate consumption of $259 \mathrm{~g}$ daily (23). Sufficient intake of lipids and proteins as well as micronutrients during pregnancy is also important for fetal growth (24), but this study is restricted to carbohydrate consumption.

In a real-world setting, we aimed to explore carbohydrate consumption and prevalence of ketonuria in early pregnancy among women with T2D including women with T1D for comparison.

2. Subjects, Materials and Methods

\subsection{Study population}

As a part of routine care since January 2013, all pregnant women referred to Center for Pregnant Women with Diabetes at Rigshospitalet have been asked to fill out a 3-day dietary record focusing on carbohydrates before their first antenatal visit at the centre. Thus, a dietary record form was sent to the women along with a welcome letter by mail. The inclusion criteria in this retrospective cohort study from August 2013 to September 2017 were: women with T2D or T1D, Danish speaking, singleton pregnancy and first antenatal visit before 20 gestational weeks. Aiming for a comparable number of women in the two diabetes groups and since data on carbohydrate consumption in 
pregnant women with T1D have already been published for the period January 2013 to December 2014 (22), we decided to include women with T1D from January 2015 to September 2017.

In the inclusion period the following women did not meet the inclusion criteria: not-Danish speaking ( $n=47$ with T2D and $n=1$ with T1D), multifetal pregnancy ( $n=10$ and $n=8)$, first antenatal visit later than 20 gestational weeks $(n=20$ and $n=2)$ and $5(n=4$ and $n=1)$ with previous bariatric surgery, resulting in 171 eligible women with T2D and 248 with T1D of which 96 (56\%) and 108 (44\%), respectively had completed the dietary records.

\subsection{Dietary analysis}

At the first antenatal visit, all women had a one-hour appointment with a specialized dietician who used the information from the dietary records as a basis for individualized dietary advice. Based on the dietary records, the dietician counted the recorded carbohydrates and used validated tables (25), photos (26) and a carbohydrate counting app, recommended by the Danish Diabetes Association, when needed. The quantity of the carbohydrates was calculated from the major carbohydrate sources only, i.e. bread products, potatoes, rice, pasta, fruits, dairy products and sweets. The major carbohydrate sources account for the majority of carbohydrates consumed e.g. a commonly recommended Danish diabetes diet for women, regardless of pregnancy, contains $1612 \mathrm{kcal}$ (6743 $\mathrm{kJ})$ including $175 \mathrm{~g}$ of carbohydrates in total (46 E\%). Of those the major carbohydrate sources account for $86 \%$ ( $150 \mathrm{~g}$ ) of the total amount of carbohydrates while $700 \mathrm{~g}$ of vegetables account for the remaining $25 \mathrm{~g}$ of carbohydrates. A pragmatic evaluation of the glycaemic index (27) based on an calculation of the total daily carbohydrate consumption was performed by the dietician in the following way: The amount of carbohydrates from low glycaemic index sources was identified and divided by the total amount of carbohydrates consumed. We stratified the glycaemic index score as $0-33 \%, 34-66 \%$ or $67-100 \%$ of carbohydrates deriving from low glycaemic index sources. Furthermore, the number of meals and snacks consumed daily and whether the women used 
carbohydrate counting in each meal and snack (yes/no) were registered, whereas total E\%, glycaemic load, lipid- and protein consumption were not assessed.

In Denmark, the recommended diet for women with diabetes, regardless of pregnancy, consists of approximately $55 \mathrm{E} \%$ of carbohydrates mainly from low glycaemic index sources with high amount of fibres $(28,29)$. In general, individualized dietary plans including 3 main meals and 2-3 snacks are tailored with respect of the women's eating habits, cultural, ethnical and economic status and presence of nausea $(28,30)$. With the aim to prevent excessive gestational weight gain and by assuming that eating more than recommended is frequent, a total daily energy intake of approximately $1673 \mathrm{kcal}(7000 \mathrm{~kJ})$ regardless of pre-pregnancy BMI or trimester is recommended for pregnant women with diabetes at our centre. The recommendation includes at least $175 \mathrm{~g}$ of carbohydrates with $150 \mathrm{~g}$ deriving from the major carbohydrate sources. The initially recommended total energy intake can be upregulated during pregnancy according to individual needs including changes in the level of physical activity aiming for appropriate weekly gestational weight gain without hunger or ketonuria. To secure sufficient intake of micro- and macronutrients, a reduction in the total energy intake is not recommended and it is our experience that upregulating the recommended energy intake is seldomly needed.

2.3 Questionnaire on physical activity and early pregnancy events

Since 2015 , the women were asked to answer a questionnaire at first antenatal visit. The questionnaire included a validated Pregnancy Physical Activity Questionnaire (PPAQ) (31) consisting of 33 questions grouped into different types of activity (i.e. household/caregiving, occupation, sports). The women could add two physical activities not listed in the questionnaire, where the intensities were individually estimated using the Compendium of Physical Activity (32). In Denmark, bicycling is very common and therefore two questions were added into the questionnaire, one on bicycling as transportation and one on bicycling as leisure activity (33). For 
each of the 35 questions, the duration of time spent in each activity was multiplied by the intensity to get the average weekly energy expenditure (metabolic equivalent of task per hour (METshr.)/wk.). The questionnaire also included non-validated questions about number of times where the women had eaten extra snacks due to hypoglycaemia the previous week, number of times where the women had eaten less or more due to nausea the previous week, number of episodes of vomiting in the previous week, number of weekly blood glucose measurements before pregnancy as well as during the previous week and average number of sleeping hours. Fifty-two percent of women with T2D and 39\% of women with T1D, answered this questionnaire at first antenatal visit.

2.4 Demographic and clinical data

Demographic and clinical data were collected from two standardized forms in the original medical records.

HbAlc was measured at the first antenatal visit in capillary blood and analysed immediately by a DCA 2000 analyser by a latex immunoagglutination inhibition method (DCA 200; Bayer, Mishawaka, IN). Early gestational weight gain was defined as the weight measured at the first antenatal visit minus self-reported weight before pregnancy $(\mathrm{kg})$. Spot urine samples were collected at the clinic in the morning hours of the visits. The occurrence of ketonuria was noted if the concentration of ketone bodies was $\geq 4.0 \mathrm{mmol} / \mathrm{L}$, detected on a dipstick of sterile urine (analysed by Siemens CLINITEK Status ${ }^{\circledR}+$ Analyzer). If urine ketone bodies $\geq 4.0 \mathrm{mmol} / \mathrm{L}$ were detected, blood ketone bodies were routinely measured (FreeStyle Precision, Abbott). Urine ketone body levels of 4.0-7.9 mmol/L corresponding to +3 on the dipstick was equivalent to a median (range) blood ketone body level of $0.2(0-0.8) \mathrm{mmol} / \mathrm{L}(\mathrm{N}=18)$ (unpublished data from our department).

\subsection{Routine diabetes care}

In Denmark, most non-pregnant women T2D receive diabetes treatment in general practice, while women with T1D are treated at local diabetes centres. The national recommendations for routine 
diabetes care aim for $\mathrm{HbAlc} \leq 7.0 \%(53 \mathrm{mmol} / \mathrm{mol})$ before pregnancy and $\leq 6.5 \%(48 \mathrm{mmol} / \mathrm{mol})$ in early pregnancy (34). The majority of women with T2D are treated with diet alone or in a combination with oral antidiabetic drugs and/or injections with Glucagon-like Peptide-1 analogue before pregnancy until pregnancy planning or at the latest up to the first antenatal visit where the treatment is changed to an insulin regimen.

\subsection{Statistical analysis}

Continuous data with normal distribution are reported as mean $( \pm$ standard deviation $(\mathrm{SD}))$, continuous data with skewed distribution as median (interquartile range (IQR)) and categorical data as number (\%). Descriptive results are given for T2D and T1D separately. Comparisons of the groups were performed by student's t-test, Mann-Whitney U-test, Chi square test or Fisher`s exact tests when appropriate.

Since the carbohydrate recommendations and carbohydrate consumption during pregnancy were similar for women with T2D and T1D, univariate regression analysis was performed in the combined cohort (T2D and T1D) as well as in the individual diabetes groups. In the univariate linear regression analyses the carbohydrate consumption per $100 \mathrm{~g}$ was used as an independent variable and $\mathrm{HbAlc}(\%)$ as an outcome variable.

The multivariate regression analysis was performed in the combined cohort only, using carbohydrate consumption per $100 \mathrm{~g}$ as independent variable and $\mathrm{HbA} 1 \mathrm{c}(\%)$ as an outcome variable with the following potential confounders; maternal age, pre-gestational BMI, daily insulin dose/bodyweight (IU/kg/24h), treatment with insulin pump (yes/no) and type of diabetes (T2D and T1D). The results of the linear regression analyses are given as the regression coefficient beta ( $\beta$ ) with a 95\% confidence interval (CI), expressing the change in the outcome variable for a unit change in the independent variable. 
Statistical analyses were performed with IBM statistics SPSS version 22. Statistically significant differences were defined as a two-sided $\mathrm{p}<0.05$.

\subsection{Ethics}

Approvals from the local Ethic committee (H-15009413) and the Danish Data Protection Agency (2007-58-0015 and 2012-58-0004) were obtained and all patients gave informed consent as appropriate according to Danish laws. The principles of The Helsinki Declaration were observed.

\section{Results}

Clinical characteristics at first antenatal visit are given in Table 1. The mean HbAlc was comparable in early pregnancy, while the women with T2D had higher prepregnancy BMI and lower weekly gestational weight gain prior to first antenatal visit than the women with T1D.

Daily carbohydrate consumption was similar in the women with T2D vs. T1D ( $159 \pm 56$ vs. $167 \pm 48$ $\mathrm{g}, \mathrm{P}=0.3$ ) with a carbohydrate consumption per bodyweight of $1.9 \pm 0.9$ vs. $2.3 \pm 0.8 \mathrm{~g} / \mathrm{kg}, \mathrm{P}<0.001$, respectively (Table 2). Fifty-two percent of the women with T2D and 40\% of the women with T1D consumed fewer carbohydrates than recommended by the IOM ( $\mathrm{P}=0.08)$ (Table 2). In the combined group of women with diabetes, the women who consumed fewer carbohydrates than recommended by the IOM had comparable HbA1c $(6.5 \pm 1.0 \%(48 \pm 11 \mathrm{mmol} / \mathrm{mol})$ vs. $6.6 \pm 1.0 \%(49 \pm 11$ $\mathrm{mmol} / \mathrm{mol}), \mathrm{P}=0.5)$ but lower weekly gestational weight gain (126 (13-260) vs. 200 (67-377) g, $\mathrm{P}=0.02)$ than the women following the IOM recommendations. Ten $(10 \%)$ women with T2D and 8 (7\%) women with T1D reported consuming $<100 \mathrm{~g}$ of carbohydrates daily (Table 2 ) with a mean daily consumption of 83 and $78 \mathrm{~g}$, respectively. None of these 18 women had ketonuria at first antenatal visit. Daily carbohydrate consumption $>200 \mathrm{~g}$ was reported by $16(17 \%)$ women with T2D and $20(19 \%)$ women with T1D. 
Among women with T2D the glycaemic index score of the carbohydrates was less favourable compared with women with T1D $(\mathrm{P}=0.04)$ and carbohydrate counting was less frequently used (Table 2).

In an univariate linear regression analysis, a significant association between daily carbohydrate consumption and HbAlc could not be detected in neither the combined cohort $(\beta: 0.13$ (95\% CI: $0.1-0.4) \%, \mathrm{P}=0.3)$ or when calculated separately for the women with $\mathrm{T} 2 \mathrm{D}(\beta: 0.2(95 \% \mathrm{CI}:-0.2-0.6)$ $\%, \mathrm{P}=0.4)$ and T1D $(\beta: 0.04(95 \% \mathrm{CI}:-0.3-0.4) \%, \mathrm{P}=0.8)$. Similar no association was found in the multiple regression analysis.

One woman with T2D and one woman with T1D had ketonuria with urine ketone concentration of 4.0-7.9 $\mathrm{mmol} / \mathrm{L}$ at first antenatal visit (Table 1). The mean carbohydrate consumption was reported to be $160 \mathrm{~g} /$ day and $121 \mathrm{~g} /$ day, respectively, and only the woman with T2D had a bedtime snack.

Data on physical activity was available in a subgroup of $56 \%$ vs. $38 \%$ patients, respectively. The total physical activity level was comparable in women with T2D and T1D (Table 3). The women with T2D spent significantly more energy on household/caregiving than the women with T1D while no difference between the groups was found in energy expenditure during occupation and sports (Table 3). A higher energy expenditure during household/caregiving was found among multipara compared to nullipara (100 (66-140) vs. 49 (30-70) METs-hr./wk., $\mathrm{P}<0.001)$.

Insulin treated women with T2D reported consuming extra carbohydrates due to episodes of hypoglycaemia twice weekly while women with T1D consumed extra carbohydrates 5.5 times/week (Table 3).

Nausea leading to eating less or more food during the previous week was reported by $54 \%$ of the women with T2D and 64\% of the women with T1D (Table 3). Nauseous women consumed $165 \pm 50$ $\mathrm{g}$ of carbohydrates daily, while women without nausea consumed $148 \pm 56 \mathrm{~g}$ daily $(\mathrm{P}=0.1)$. 
Among the women with T2D, a high number were of non-North-European Origin. The carbohydrate consumption in the women with T2D of North-European origin was comparable with women of non-North-European origin ( $165 \pm 60$ vs. $154 \pm 53 \mathrm{~g}, \mathrm{P}=0.4)$ as was the number of women consuming $\leq 150$ g carbohydrates daily ( $46 \%$ vs. $58 \%, \mathrm{P}=0.3)$. HbAlc was $6.8 \pm 1.3 \%(51 \pm 14$ $\mathrm{mmol} / \mathrm{mol})$ vs. $6.4 \pm 1 \%(47 \pm 11 \mathrm{mmol} / \mathrm{mol}) \mathrm{P}=0.2$, in women of North-European origin vs. nonNorth-European origin.

\section{Discussion}

This cohort study from Denmark, in a real-world setting, demonstrates that the women with T2D often consumed fewer carbohydrates than recommended by the IOM in early pregnancy. The average carbohydrate consumption from the major carbohydrate sources was similar in women with T2D and T1D. Women with T2D weighted on average $15.3 \mathrm{~kg}$ more than women with T1D and ketonuria in early pregnancy was rare in both groups.

The average carbohydrate consumption in this study was lower than previously described for women with T2D (23), T1D (22) and healthy pregnant women where 286 and $393 \mathrm{~g}$ daily has been reported $(7,8)$, even if the expected $25 \mathrm{~g}$ from the minor sources is added. In healthy women, carbohydrate consumption throughout pregnancy has been reported rather stable with an average $4 \%$ higher consumption in late pregnancy $(7,8,35)$. In both our and the Canadian study $(23)$, the average carbohydrate consumption was similar in women with T2D and T1D while the bodyweight was approximately $15 \mathrm{~kg}$ higher in women with T2D. This may reflect similar intake of the total energy or a different distribution in the macronutrient consumption with higher fat and/or protein intake in obese women compared with normal weight women.

The minimum amount of carbohydrates required to prevent ketosis is 50 to $100 \mathrm{~g}$ daily outside of pregnancy (36). During third trimester, the fetal brain is estimated to use approximately $35 \mathrm{~g}$ of 
carbohydrates per day as an energy source (6) and additional carbohydrates are used for fetal growth.

A high proportion of women in our study reported an intake of fewer carbohydrates than recommended by the IOM. Older studies have raised concern about the adverse effect of ketone bodies on the developing fetal brain in pregnancies complicated with diabetes $(15,16)$. An inverse correlation between the mothers' third trimester plasma $\beta$-hydroxybutyrate and children's intelligence both at the age of 2 and 3-5 years has been reported (15). A recent study from our own group reported lower intelligence in teenage offspring of mothers suffering from ketoacidosis during pregnancy, but numbers were small (37). Therefore, it is reassuring that the occurrence of ketonuria in early pregnancy was low in the present study.

In contrast to our previous findings (22), we did not observe an association between carbohydrate consumption and HbAlc in this cohort. This may be due to a lower number of women with a carbohydrate consumption exceeding $200 \mathrm{~g}$ daily and less variation in HbA1c in the present cohort. Carbohydrate counting is important to obtain tight glycaemic control with a flexible lifestyle in patients with T1D who do not have an endogenous insulin production $(22,38)$ and was frequently used in the investigated women. Carbohydrate counting in women with T2D was rare and whether pregnant women with $\mathrm{T} 2 \mathrm{D}$ also benefit from carbohydrate counting needs to be investigated.

To our knowledge, this is the largest study to date, evaluating the carbohydrate consumption in early pregnancy as part of routine care in a cohort of women with T2D in a real-world setting, including data on ketonuria, nausea and vomiting. The evaluation of the carbohydrate consumption is meaningful for insulin treated patients and diabetes caregivers. The same dietician (HR) evaluated the amount of carbohydrates consumed and the glycaemic index score which gives consistency of the method. 
It is a limitation that the women's carbohydrate consumption was self-reported and the total E\%, glycaemic load, lipid- and protein consumption were not recorded. To minimize the recall bias, the women were asked to complete the dietary records prospectively over 3 days before the first antenatal visit. The women may have chosen a healthier diet during the dietary registration and/or omitted to register all carbohydrates from the major carbohydrates consumed. It is known that less healthy eaters are more likely to underreport food intake (39). Despite these limitations, this is one of the best options for evaluation of carbohydrate consumption in a large population. All eligible women reporting at least one day of dietary records were included in the study to improve the external validity of the study, but this might have biased the estimation of the daily carbohydrate consumption. It would have added value to our study, if the women had tested for ketonuria at home the same days as the dietary registration. There is a risk of selection bias as the less compliant women with unhealthy eating habits may not have filled out the dietary records. Data from the PPAQ was only available in 52\% and 39\% of included women with T2D and T1D, respectively.

\subsection{Conclusions}

In early pregnancy, a lower daily carbohydrate consumption than recommended by the IOM was common among women with T2D. The results were quite similar to women with T1D, despite a markedly higher bodyweight in women with T2D. Reassuringly, ketonuria was rare in both groups. Future studies should focus on the safety of consuming a low amount of carbohydrates during pregnancy in women with diabetes.

\section{Acknowledgements}

Author Contributions. E.R.M. and B.Á. contributed to the idea. H.R. conducted the diet analyses in the women. B.Á and M.V. collected the data. B.Á. analysed data and wrote the manuscript. All authors were involved in the interpretation of data, contributed to the discussion, reviewed and edited the manuscript and approved the final version. E.R.M. is the guarantor of this work and, as 

such, has full access to all the data in the study and takes responsibility for the integrity of the data

339 and the accuracy of the data analysis.

340 Statements of assistance. We kindly thank midwife at Rigshospitalet, Maria Anna Mikkelsen for

341 helping with the data collection.

342 Funding. This study was supported by The Novo Nordisk Foundation. The sponsor of the study was 343 not involved in design, conduct, or interpretation of the study.

344 Conflicts of interest. No potential conflicts of interest relevant to this article were reported. 
Reference List

1. Persson M, Norman M, Hanson U: Obstetric and perinatal outcomes in type 1 diabetic pregnancies: A large, population-based study. Diabetes Care 32:2005-2009, 2009

2. Sugrue R, Zera C: Pregestational Diabetes in Pregnancy. Obstet Gynecol Clin North Am 45:315-331, 2018

4. Sheard NF, Clark NG, Brand-Miller JC, Franz MJ, Pi-Sunyer FX, Mayer-Davis E, Kulkarni K, Geil P: Dietary carbohydrate (amount and type) in the prevention and management of diabetes: a statement by the american diabetes association. Diabetes Care 27:2266-2271, 2004

5. 13. Management of Diabetes in Pregnancy: Standards of Medical Care in Diabetes-2018. Diabetes Care 41:S137-S143, 2018

6. Institute of Medicine of the National Academies. Dietary Reference Intakes for Energy, Carbohydrate, Fiber, Fat, Fatty Acids, Cholesterol, Protein and Amino Acids (Macronutrients). 2005. Washington DC, National Academy Press.

7. Diemert A, Lezius S, Pagenkemper M, Hansen G, Drozdowska A, Hecher K, Arck P, Zyriax BC: Maternal nutrition, inadequate gestational weight gain and birth weight: results from a prospective birth cohort. BMC Pregnancy Childbirth 16:224, 2016

10. Freedman MR, King J, Kennedy E: Popular diets: a scientific review. Obes Res 9 Suppl 1:1S-40S, 2001

11. Kirk JK, Graves DE, Craven TE, Lipkin EW, Austin M, Margolis KL: Restricted-carbohydrate diets in patients with type 2 diabetes: a meta-analysis. J Am Diet Assoc 108:91-100, 2008

12. Felig $\mathrm{P}$, Lynch V: Starvation in human pregnancy: hypoglycemia, hypoinsulinemia, and hyperketonemia. Science 170:990-992, 1970

13. Knopp RH, Magee MS, Raisys V, Benedetti T, Bonet B: Hypocaloric diets and ketogenesis in the management of obese gestational diabetic women. J Am Coll Nutr 10:649-667, 1991 
14. Rasmussen KM, Yaktine AL: Weight Gain During Pregnancy: Reexamining the Guidelines. [article online], 2009. Available from http://www.nap.edu/catalog.php?record id=12584. Accessed 29 April 2012

15. Rizzo T, Metzger BE, Burns WJ, Burns K: Correlations between antepartum maternal metabolism and child intelligence. N Engl J Med 325:911-916, 1991

16. Stehbens JA, Baker GL, Kitchell M: Outcome at ages 1, 3, and 5 years of children born to diabetic women. Am J Obstet Gynecol 127:408-413, 1977

17. Egan AM, Dennedy MC, Al-Ramli W, Heerey A, Avalos G, Dunne F: ATLANTIC-DIP: excessive gestational weight gain and pregnancy outcomes in women with gestational or pregestational diabetes mellitus. J Clin Endocrinol Metab 99:212-219, 2014

18. Parellada CB, Asbjornsdottir B, Ringholm L, Damm P, Mathiesen ER: Fetal growth in relation to gestational weight gain in women with type 2 diabetes: an observational study. Diabet Med 31:16811689, 2014

19. Secher AL, Parellada CB, Ringholm L, Asbjornsdottir B, Damm P, Mathiesen ER: Higher gestational weight gain is associated with increasing offspring birth weight independent of maternal glycemic control in women with type 1 diabetes. Diabetes Care 37:2677-2684, 2014

20. Jovanovic L: Role of diet and insulin treatment of diabetes in pregnancy. Clin Obstet Gynecol 43:4655,2000

21. 4. Lifestyle Management: Standards of Medical Care in Diabetes-2018. Diabetes Care 41:S38-S50, 2018

22. Asbjornsdottir B, Akueson CE, Ronneby H, Rytter A, Andersen JR, Damm P, Mathiesen ER: The influence of carbohydrate consumption on glycemic control in pregnant women with type 1 diabetes. Diabetes Res Clin Pract 127:97-104, 2017

23. McManus RM, Bouwmeester A, Hinz L, Caraiscos VB, Nairn J, Giroux I: Costs of recalled and recommended diets for pregnant women with type 1 , type 2 and gestational diabetes. Can J Diabetes 37:301-304, 2013

24. Abu-Saad K, Fraser D: Maternal nutrition and birth outcomes. Epidemiol Rev 32:5-25, 2010

25. Ygil KH. Mål, vægt og portionsstørrelser på fødevarer. [article online], 2013. Available from http://orbit.dtu.dk/files/54035130/maal vaegt portionsstoerrelser marts 13.pdf. Accessed 12 April 2018. Danmarks Tekniske Universitet, Fødevareinstituttet.

26. Nielsen TH, Biltoft-Jensen AP, and Ygil KH. Udvikling af billedserier til Den nationale unders $\varnothing$ gelse af danskernes kostvaner og fysiske aktivitet 2011. [article online], Nov 2011. Available from http://www.food.dtu.dk/Publikationer/Ernaering-og-kostvaner/De nationale kostundersoegelser. Accessed 12 April 2018. Danmarks Tekniske Universitet, Fødevareinstituttet.

27. Atkinson FS, Foster-Powell K, Brand-Miller JC: International tables of glycemic index and glycemic load values: 2008. Diabetes Care 31:2281-2283, 2008 
28. Knold B, Wolff C, Jensen B, and Brown P. Diætbehandling ved prægestationel diabetes mellitus. [article online], 2006. Available from https://www.diaetist.dk/media/1904/03FaKD Rammeplan pregestationel\%20diabetes\%20mellitus\% 202006.pdf Accessed 3 April 2019. Foreningen af kliniske diætister.

29. Schelde B, Pallesen B, and Sode V. Diætbehandling ved type 1 diabetes mellitus. [article online], 2011. Available from https://www.diaetist.dk/media/1928/FaKD diaetbeh type1 voksne2011.pdf Accessed 7 May 2019. Foreningen af kliniske diætister.

30. Roskjaer AB, Andersen JR, Ronneby H, Damm P, Mathiesen ER: Dietary advices on carbohydrate intake for pregnant women with type 1 diabetes. J Matern Fetal Neonatal Med 28:229-233, 2015

31. Chasan-Taber L, Schmidt MD, Roberts DE, Hosmer D, Markenson G, Freedson PS: Development and validation of a Pregnancy Physical Activity Questionnaire. Med Sci Sports Exerc 36:1750-1760, 2004

32. Ainsworth BE, Haskell WL, Herrmann SD, Meckes N, Bassett DR, Jr., Tudor-Locke C, Greer JL, Vezina J, Whitt-Glover MC, Leon AS: 2011 Compendium of Physical Activities: a second update of codes and MET values. Med Sci Sports Exerc 43:1575-1581, 2011

33. Simmons D, Devlieger R, van AA, Jans G, Galjaard S, Corcoy R, Adelantado JM, Dunne F, Desoye G, Harreiter J, Kautzky-Willer A, Damm P, Mathiesen ER, Jensen DM, Andersen L, Lapolla A, Dalfra MG, Bertolotto A, Wender-Ozegowska E, Zawiejska A, Hill D, Snoek FJ, Jelsma JG, van Poppel MN: Effect of Physical Activity and/or Healthy Eating on GDM Risk: The DALI Lifestyle Study. J Clin Endocrinol Metab 102:903-913, 2017

34. Secher AL, Ringholm L, Andersen HU, Damm P, Mathiesen ER: The Effect of Real-Time Continuous Glucose Monitoring in Pregnant Women With Diabetes: A randomized controlled trial. Diabetes Care 36:1877-1883, 2013

35. Kubota K, Itoh H, Tasaka M, Naito H, Fukuoka Y, Muramatsu KK, Kohmura YK, Sugihara K, Kanayama $\mathrm{N}$ : Changes of maternal dietary intake, bodyweight and fetal growth throughout pregnancy in pregnant Japanese women. J Obstet Gynaecol Res 39:1383-1390, 2013

36. Calloway DH: Dietary components that yield energy. Environ Biol Med 1:175-186, 1972

37. Bytoft B, Knorr S, Vlachova Z, Jensen RB, Mathiesen ER, Beck-Nielsen H, Gravholt CH, Jensen DM, Clausen TD, Mortensen EL, Damm P: Long-term Cognitive Implications of Intrauterine Hyperglycemia in Adolescent Offspring of Women With Type 1 Diabetes (the EPICOM Study). Diabetes Care 39:13561363,2016

38. Hommel E, Schmidt S, Vistisen D, Neergaard K, Gribhild M, Almdal T, Norgaard K: Effects of advanced carbohydrate counting guided by an automated bolus calculator in Type 1 diabetes mellitus (StenoABC): a 12-month, randomized clinical trial. Diabet Med 34:708-715, 2017

39. Muhlheim LS, Allison DB, Heshka S, Heymsfield SB: Do unsuccessful dieters intentionally underreport food intake? Int J Eat Disord 24:259-266, 1998 
Table 1. Clinical characteristics of pregnant women with type 2 diabetes compared with pregnant women with type 1 diabetes at first antenatal visit.

\begin{tabular}{|l|l|l|l|}
\hline & Type 2 diabetes & Type 1 diabetes & P-value \\
\hline Number & 96 & 108 & \\
\hline Age (years) & $34 \pm 5$ & $31 \pm 5$ & 0.001 \\
\hline Duration of diabetes (years) & $3(1-6)$ & $16(9-22)$ & $<0.001$ \\
\hline Prepregnancy weight (kg) & $89.5 \pm 23$ & $73.4 \pm 15$ & $<0.001$ \\
\hline Prepregnancy diet treatment only & $23(24 \%)$ & & \\
\hline Prepregnancy oral antidiabetic medication ${ }^{\dagger}$ & $60(63 \%)$ & & \\
\hline $\begin{array}{l}\text { Prepregnancy treatment with Glucagon-Like- } \\
\text { Peptide-1-antagonist }\end{array}$ & $9(9 \%)$ & & \\
\hline Height (cm) & $165 \pm 7$ & $168 \pm 6$ & 0.001 \\
\hline Prepregnancy BMI (kg/m $\left.{ }^{2}\right)$ & $32.8 \pm 7$ & $26.0 \pm 5$ & $<0.001$ \\
\hline North-European Origin & $52(55 \%)$ & $98(93 \%)$ & $<0.001$ \\
\hline Nulliparous & $36(38 \%)$ & $55(51 \%)$ & 0.06 \\
\hline Smoking & $2 / 49(4 \%)$ & $1 / 43(2 \%)$ & 0.6 \\
\hline Gestational age (days) & $71(60-87)$ & $63(56-76)$ & 0.003 \\
\hline HbAlc (\%) $(m m /$ mol) & $6.6 \pm 1.2$ & $6.6 \pm 0.8$ & 0.8 \\
\hline Insulin treatment & $49 \pm 13$ & $48 \pm 8$ & \\
\hline Insulin pump treatment & $18(19 \%)$ & $108(100 \%)$ & - \\
\hline Insulin dose (IU/kg/24h) $)^{\S}$ & $0 \%$ & $36(33 \%)$ & - \\
\hline Weight (kg) & $0.67 \pm 0.40$ & $0.61 \pm 0.28$ & 0.6 \\
\hline Early gestational weight gain (kg) & $90.8 \pm 22$ & $75.5 \pm 15$ & $<0.001$ \\
\hline Early weekly gestational weight gain (g) & $1.5 \pm 2.7$ & $2.1 \pm 2.1$ & 0.07 \\
\hline Ketonuria ( $\geq 4.0$ mmol/L) & $145 \pm 247$ & $233 \pm 230$ & 0.01 \\
\hline Da & $1(1 \%)$ & $1(1 \%)$ & 1.0 \\
\hline
\end{tabular}

Data are given as mean \pm standard deviation, median (interquartile range) or $\mathrm{n}(\%)$. $\uparrow$ Monotherapy with Biguanide $(\mathrm{N}=39)$. Combination therapy with Biguanide and Glucagon-Like-Peptide-1-antagonist (GLP-1-antagonist) $(\mathrm{N}=6)$, Dipeptidyl Peptidase-IV (DPP-IV) Inhibitors ( $\mathrm{N}=6$ ), Sodium-Glucose co-Transporter-2 (SGLT2) Inhibitors $(\mathrm{N}=1)$ Sulphonylureas $(\mathrm{N}=1)$ and insulin $(\mathrm{N}=6)$ respectively. Combination therapy with Biguanide, DPP-IV-Inhibitor and SGLT-2-Inhibitor $(\mathrm{N}=1)$. \$Monotherapy with GLP-1-antagonist $(\mathrm{N}=1)$. Combination therapy with GLP-1-antagonist and Biguanide $(\mathrm{N}=6)$ and insulin $(\mathrm{N}=2)$, respectively. $\S$ Numbers are given for those on insulin treatment. 
Table 2. Dietary analysis based on dietary records in early pregnancy by women with type 2

468 diabetes and women with type 1 diabetes.

\begin{tabular}{|c|c|c|c|}
\hline & Type 2 diabetes & Type 1 diabetes & P-value \\
\hline Number & 96 & 108 & \\
\hline $\begin{array}{l}\text { Dietary records } \\
\text { - } 1 \text { day } \\
-2 \text { days } \\
\text { - } 3 \text { days }\end{array}$ & $\begin{array}{l}12(12 \%) \\
15(16 \%) \\
69(72 \%) \\
\end{array}$ & $\begin{array}{l}32(30 \%) \\
23(21 \%) \\
53(49 \%)\end{array}$ & 0.002 \\
\hline Carbohydrate consumption (g/day) & $159 \pm 56$ & $167 \pm 48$ & 0.3 \\
\hline $\begin{array}{l}\text { Carbohydrate consumption/kg bodyweight } \\
\text { (g/kg/day) }\end{array}$ & $1.9 \pm 0.9$ & $2.3 \pm 0.8$ & $<0.001$ \\
\hline $\begin{array}{l}\text { Consuming fewer carbohydrates than } \\
\text { recommended by the Institute of Medicine }\end{array}$ & $50(52 \%)$ & $43(40 \%)$ & 0.08 \\
\hline Consuming $<100 \mathrm{~g}$ of carbohydrates & $10(10 \%)$ & $8(7 \%)$ & 0.5 \\
\hline 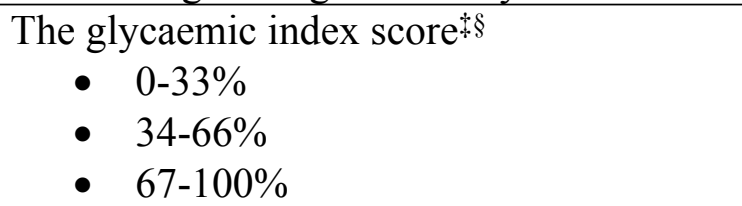 & $\begin{array}{l}13(18 \%) \\
21(30 \%) \\
37(52 \%)\end{array}$ & $\begin{array}{l}6(6 \%) \\
36(36 \%) \\
57(58 \%)\end{array}$ & 0.04 \\
\hline Use of carbohydrate counting & $6(6 \%)$ & $83(77 \%)$ & $<0.001$ \\
\hline 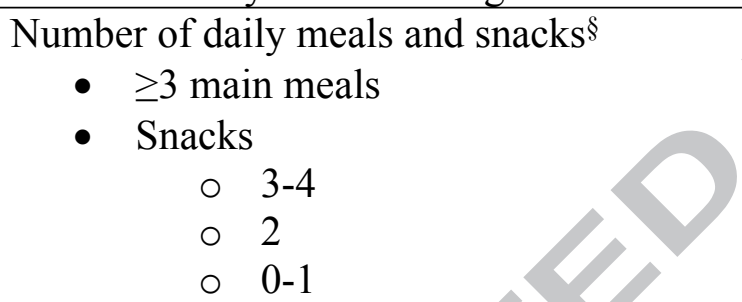 & $\begin{array}{l}74(96 \%) \\
29(38 \%) \\
17(22 \%) \\
30(40 \%)\end{array}$ & $\begin{array}{l}75(94 \%) \\
46(58 \%) \\
22(27 \%) \\
12(15 \%)\end{array}$ & $\begin{array}{l}0.7 \\
0.002\end{array}$ \\
\hline
\end{tabular}

Data are given as $\mathrm{n}(\%)$ or mean \pm standard deviation. Carbohydrates calculated from the major carbohydrate sources. $\dagger \leq 150$ g daily. $\$$ A score of $67-100 \%$ means that the majority of recorded carbohydrates derived from low glycaemic 
Table 3. Eating behaviour and lifestyle in pregnant women with type 2 or type 1 diabetes in early pregnancy.

\begin{tabular}{|c|c|c|c|}
\hline & Type 2 diabetes & Type 1 diabetes & P-value \\
\hline Number & 54 & 42 & \\
\hline $\begin{array}{l}\text { Total physical activity (METs-h/wk.) }{ }^{\dagger} \\
\text { - Household/caregiving } \\
\text { - Occupation } \\
\text { - Sports } \\
\text { - Other }\end{array}$ & $\begin{array}{l}215(174-289) \\
85(50-136) \\
71(0-106) \\
11(3-19) \\
49(34-67)\end{array}$ & $\begin{array}{l}210(178-267) \\
57(36-82) \\
81(71-108) \\
10(4-16) \\
63(44-77)\end{array}$ & $\begin{array}{l}0.9 \\
0.002 \\
0.06 \\
0.9 \\
0.02\end{array}$ \\
\hline $\begin{array}{l}\text { Number of extra snacks eaten due to } \\
\text { hypoglycaemia in the previous week }\end{array}$ & $2(0-6)$ & $5.5(3-8)$ & 0.005 \\
\hline $\begin{array}{l}\text { Changed eating behaviour due to nausea in the } \\
\text { previous week } \\
\text { - Eating less due to nausea } \geq 1 / \text { wk. } \\
\text { - Number of times eating less due to } \\
\text { nausea/wk. } \\
\text { - Eating more due to nausea } \geq 1 / \mathrm{wk} \text {. } \\
\text { - Number of times eating more due to } \\
\text { nausea/wk. } \\
\text { - Eating less or more due to nausea } \geq 1 / \mathrm{wk} \\
\text { Vomiting in the previous week } \\
\text { - Number of vomiting/wk. }\end{array}$ & $\begin{array}{l}24(44 \%) \\
3(1.5-6) \\
15(29 \%) \\
3(2-7) \\
29(54 \%) \\
12(23 \%) \\
2(1-3)\end{array}$ & $\begin{array}{l}19(49 \%) \\
2(1-5) \\
17(41 \%) \\
6(2-7) \\
27(64 \%) \\
14(34 \%) \\
1.5(1-5)\end{array}$ & $\begin{array}{l}0.7 \\
0.4 \\
0.2 \\
0.3 \\
\\
0.3 \\
\\
0.2 \\
0.5\end{array}$ \\
\hline $\begin{array}{l}\text { Number of blood glucose measurements/wk. } \\
\text { before pregnancy }\end{array}$ & $0.5(0-5)$ & $30(7-50)$ & $<0.001$ \\
\hline $\begin{array}{l}\text { Number of blood glucose measurements in the } \\
\text { previous week }\end{array}$ & $48(24-49)$ & $60(30-70)$ & 0.001 \\
\hline Sleeping hours $/ 24 \mathrm{~h}$ in the previous week & $7.7 \pm 1.3$ & $7.9 \pm 1.0$ & 0.5 \\
\hline
\end{tabular}

